\title{
Spatio-temporal variation of insects with immature phase in the soil of Cerrado Northeast of Brazil
}

Holometabolous insects use multiple substrates for ovipositon, laying their eggs on fruits, seeds, and animal tissues, with many species deposit them directly on the soil. The study aimed to identify the families of winged insects with an immature phase in the soil and to verify the effect of climatic seasonality in this insect guild in different conditions of soil cover in a cerrado area in Northern Brazil. The adult insects were sampled at four sites: I - capoeira forest with litter, II - capoeira forest without litter, III - gallery forest with litter, and IV - gallery forest with litter. In each sample site was installed 6 emergency traps, equidistant $5 \mathrm{~m}$ from each other. The traps remained in the field for 20 months, occupying five different points in the $150 \mathrm{~m}$ transections plotted at each sampling site. The collect of newly emerged adult insects was carried out weekly, using a suction tube, and identified in family level. The soils of the sampling sites were characterized chemically and physically, as well as the climatic factors (humidity and temperature). In this study, a large number of families of insects with immature phase were sampled in soils of a region that makes up three larges Brazilian biomes: Cerrado, Caatinga, and Amazon. The number of insect families sampled was affected by climatic seasonality but was not affected by spatial variation. The diversity rates recorded in this study were high, with the highest values recorded in the sampling sites where the litter layer was preserved, evidencing the role of litter and soil organic matter in preserving and maintaining the biological diversity of the soil.

Keywords: Habitat; Seasonality; Soil Macrofauna.

\section{Variação espaço-temporal de insetos com fase imatura no solo do Cerrado Nordeste do Brasil}

\begin{abstract}
Os insetos holomoetábolos utilizam múltiplos substratos para oviposição, colocando seus ovos em frutos, sementes e tecidos animais, com muitas espécies depositando-os diretamente no solo. O objetivo deste estudo foi identificar as famílias de insetos alados com fase imatura no solo e verificar o efeito da sazonalidade climática nesta guidla guilda de insetos em diferentes condições de cobertura do solo em uma área de Cerrado Setentrional do Brasil. Os insetos adultos foram amostrados em quatro ambientes: I- mata de capoeira com serapilheira, II - mata de capoeira sem serapilheira, III - mata de galeria com serapilheira e IV - mata de galeria sem serapilheiral. Em cada ambiente de amostragem foram instaladas 6 armadilhas de emergência, equistantes $5 \mathrm{~m}$ uma da outra. As armadilhas permaneceram em campo durante 20 meses, ocupando cinco pontos diferentes nas transecções de $150 \mathrm{~m}$ plotadas em cada local de amostragem. A coleta dos insetos recém emergidos foi realizada semanalmente, com auxílio de um tubo de sucção, e identificadas em nível de família. Os solos dos locais de amostragem foram caracterizados química e fisicamente, bem como os fatores climáticos (umidade e temperatura). Neste estudo amostrou-se um amplo número de famílias de insetos com fase imatura em solos de uma região que compõe três grandes biomas brasileiros: o Cerrado, a Caatinga e a Amazônia. O número de famílias de insetos amostradas foi afetado pela sazonalidade climática, mas não foi afetado pela variação espacial. Os índices de diversidade registrados neste estudo foram elevados, com maiores valores registrados nos locais de amostragem onde a camada de serapilheira foi preservada, evidenciando o papel da serapilheira e da matéria orgânica do solo na preservação e manutenção da diversidade biológica do solo.
\end{abstract}

Palavras-chave: Habitat; Sazonalidade; Macrofauna do solo.

Topic: Ciências do Solo

Reviewed anonymously in the process of blind peer.
Received: 08/06/2021

Approved: 24/06/2021
Edison Fernandes da Silva (in)

Universidade Federal do Maranhão, Brasil http://lattes.cnpq.br/3962858158135882

http://orcid.org/0000-0001-8696-6831

edibocaiuva@yahoo.com.br

Francinaldo Soares Silva (iD)

Universidade Federal do Maranhão, Brasil http://lattes.cnpq.br/3390673784617972

http://orcid.org/0000-0002-1356-7431

francinaldo.silva@ufma.br

Luana Nascimento Silva (iD)

Universidade Federal do Maranhão, Brasil

http://lattes.cnpq.br/9145331043920235

http://orcid.org/0000-0002-7000-9313

charlyan.lima@universo.univates.br

a

DOI: 10.6008/CBPC2179-6858.2021.006.0003
Charlyan de Sousa Lima (iD

Universidade Federal do Maranhão, Brasi http://lattes.cnpq.br/1033417364789024 http://orcid.org/0000-0002-6100-0325 charlyansl@yahoo.com.br

\section{Referencing this:}

SILVA, E. F.; SILVA, F. S.; SILVA, L. N.; LIMA, C. S.. Spatio-temporal variation of insects with immature phase in the soil of Cerrado Northeast of Brazil. Revista Ibero Americana de Ciências Ambientais, v.12, n.6, p.30-44, 2021. DOI: http://doi.org/10.6008/CBPC21796858.2021 .006 .0003 


\section{INTRODUCTION}

Insects are spatially and temporally distributed according to climatic factors, such as temperature, humidity, winds, atmospheric pressure, and sunlight (JAWORSKI et al., 2013; BAPTISTA et al., 2014; FOURCADE et al., 2017). Temperature and humidity are parameters of greater strength in defining the areas of insect occurrence (LEPAGE et al., 2012; ROBINSON et al., 2018), mainly for insects with edaphic habits, because in soils, these two factors are more prominent without removing the effects of other climatic parameters that affect less edaphic insects.

The soil biota has morphological adaptations, such as body lengthening, reduction of appendages, vestialization or loss of vision, modifications of appendages and tagmas for soil removal and transport (MCCOLLOCH et al., 1992). Adaptive adjustments also involve changes in physiology and behavioral aspects, especially in insects (SHEIKH et al., 2017; CULVER et al., 2018). These adaptations are more conspicuous and can be observed both in organisms that live strictly in the soil and in those that occupy the soil temporarily, as well as the immature forms of insects.

Hemimetabolous insects, especially holometabolas, develop immature phases in specific niches and occupy different substrates, such as water, live and decomposing trunks, dead animal carcasses, parasitizing other animals (parasitoids), and often in different soil layers (DUAN et al., 2019; YANG et al., 2020). In the pedological stratum, a wide variety of immature forms of insects can be found, including adult winged forms that have at least one stage of development in the pedological horizons.

In the pedological environment, immature and mature forms of insects are affected by soil texture, density, aeration status, and nutritional status, among others (ROSA et al., 2015; POMPEO et al., 2016). The multiplicity of edaphoclimatic factors that affect the organisms residing in soils requires the improvement of collection methodologies these organisms. Samples of biological soil material can be obtained directly from manual collection and indirectly. In this last method, samples are obtained by Berliese Tüllgren Funnel, Macfadyen High Grader Extractor and Kempson Infrared Extractor (CORREA et al., 2000).

Winged insects lay eggs in water, on the bark of trees, litter, and topsoil. Insect larvae can be observed from the $20 \mathrm{~cm}$ layer of the soil to 2 meters (OLIVEIRA et al., 2004; CAJAIBA et al., 2017). Insects with an immature stage in the soil form an erratically known guild. The identification of this group, in the Cerrado environment, adds relevant information to the biology of the families of insects investigated, especially in adulthood.

Many studies with immature soil insects or insects residing in the soil reach groups that include Tipulidae, Psychodidae, Sciaridae, Tipulidae, Sciaridae, Bibionidae, Chrysomelidae, Stratiomyiidae, Muscidae, Anthomyiidae, Carabidae, Cantharidae, and Dolichopodidae (BENEFER et al., 2016).

Most of these studies, which involve the immature phase of insects, refer to the aquatic environment (URBINATTI et al., 2001; SILVA et al., 2020), fecal beds of bovines and birds (ZIMMER et al., 2006), and address insects of medical and agricultural importance. In studies of insects with an immature phase in the soil, the emphasis is on taxonomy, reproductive biology, and biogeography. However, there are studies that highlight 
the effects of physical and chemical attributes of soil on the rate of oviposition and emergence of immature insects in the soil (RIIS et al., 1998; OLIVEIRA et al., 2004; RIIS et al., 2005).

The main orders of insects found in soils are Coleoptera, Diptera, and Hymenoptera, which for the most part, are found in the $0-5 \mathrm{~cm}$ layer (SEFFRIN et al., 2006). Insects that occupy the first $5 \mathrm{~cm}$ of the soil are more exposed to thermal variations, humidity, and other factors that can cause their displacement to other layers of the soil. Variations in the content of organic matter drastically affect the distribution of edaphic insects, with direct impacts on food availability for populations of Scarabeideos, Curculionídeos, and Elaterideo (MERLIM et al., 2006). In native forests, the families of Staphylinidae, Carabidae, and Scarabaeidae are quite abundant due to the high levels of organic matter and biopores found in natural systems (CAJAIBA et al., 2015; 2017; POMPEO et al., 2016). In these environments, the greatest wealth and abundance of the arthropodofauna depends on the quantity and variety of food resources and, consequently, the heterogeneity/complexity of the forest environment (MAESTRI et al., 2013; LIMA et al., 2020b).

The abundance and quality of soil organic matter and litter create microenvironments suitable for biocenosis of insects residing in the soil or that use the soil temporarily, depositing eggs that evolve into larvae and emerge as adults. The study of insects with an immature phase in the soil is quite relevant as it adds important data about the biology of the insects studied, especially in the Cerrado, as studies of this nature were carried out in the Amazon and Atlantic Forest (CASANOVA, 2001; ALENCAR, 2007). In this sense, this study was proposed to (1) identify the families of winged insects with an immature phase in the soil and (2) verify the effect of climatic seasonality in the population of this guild of insects under different conditions of soil cover in four Cerrado environments of Northern Brazilian ecotone.

\section{METHODOLOGY}

\section{Study Area}

The study was carried out at Reserva do Itamacaoca, located in the municipality of Chapadinha - MA $\left(3^{\circ} 44^{\prime} 31^{\prime \prime} \mathrm{S}\right.$ and $\left.43^{\circ} 21^{\prime} 36^{\prime \prime} \mathrm{W}\right)$. The area consists of a mosaic of vegetation formations, including riparian and gallery forests (tree vegetation established along water courses, associated with springs), preserved and no preserved savana fields, forming capoeiras forests.

\section{Sampling}

The study was conducted in two environments: secondary forest - capoeira and gallery forest. Each of these environments was divided into two sub-environments forming the sites: I - capoeira forest with litter, II - capoeira forest without litter, III - gallery forest with litter, and IV - gallery forest with litter, in each at the four sites was ploted transects with $150 \mathrm{~m}$ each. In sites without litter, the litter layer was removed only at the trap installation site. In each sampling site, 6 traps, $5 \mathrm{~m}$ equidistant from each other, were installed to capture insects emerging from the soil (Figure 1).

Each trap, pyramid-shaped, contained the following measurements: $A b$ - base area $=0.25 \mathrm{~m}^{2}, \mathrm{~h}$ - 
height of $0.5 \mathrm{~m}$, and a volume of $0.041 \mathrm{~m}^{3}$, obtained from the formula pyramid volume $=1 / 3 \times A b \times \mathrm{h}$. Considering that the soil area covered by each trap was $0.25 \mathrm{~m}^{2}$ and that each trap was repositioned five times during the study, the total area of soil covered by the traps was $30 \mathrm{~m}^{2}$, with $7.5 \mathrm{~m}^{2}$ for each sample site. The traps were made to form a pyramidal design, which added the newly emerged insects to the top of the respective traps. The material used was iron bars $4.2 \mathrm{~mm}$ in diameter and $70 \mathrm{~cm}$ long, with $20 \mathrm{~cm}$ of the bases fixed inside the soil and the upper vertex joining the iron bars with the aid of annealed iron wire. Voile fabric ( $100 \%$ polyester round the world) was used to cover the traps, being previously sewn in the measures of the iron structure and with a velcro opening of $0.15 \mathrm{~m}$ in length on one side of the traps to allow collection of the samples.

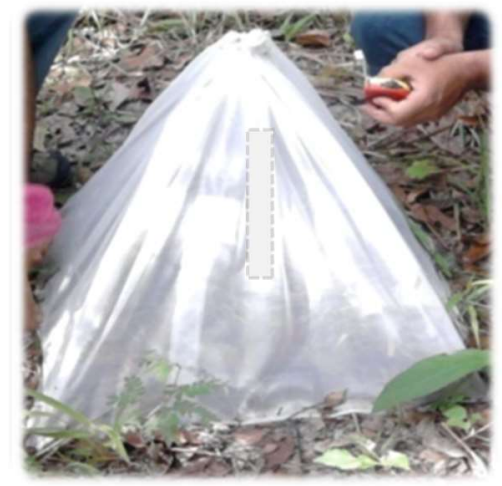

Figure 1: Emergency trap used to capture adult insects with an immature stage in the soil in an area of the Northeast Cerrado of the State of Maranhão, Brazil. Scale 1:10.

The spatial distribution of the traps at each site was changed within the respective transections, avoiding sub-sampling due to depletion of individuals under the area delimited by the trap, so that over the 20 months of sampling, the traps were distributed at five different points within $150 \mathrm{~m}$ from each transection.The sampling points within each transection were distributed as follows: P1 (0-30 m; period 01/2010 to 04/2010), P2 (31-60 m; period from 05/2010 to 08/2010), P3 (61-90 m; period from 09/2010 to 12/2010), P4 (91-120 m; period from 01/2011 to 04/2011), and P5 (121-150 m; period 05/2011 to 08/2011). The spatial redistribution of the traps in each transection allowed the rainy seasons to be sampled in the following periods: (P1), drought rain transition (P2), drought season (P3), rainy season (P4), and transition from the rainy season to the dry season (P5).

The collection of newly emerged adult insects was carried out weekly for 20 months from January 2010 to August 2011. In the collection of insects, a suction tube was used. During the weekly collections, atmospheric temperature and humidity measurements were taken.The sampled individuals were conserved in $70 \%$ alcohol and identified at the family level, with the help of Borror et al. (2005) dichotomous key. The collected material was deposited in the Soil Arthropod laboratory of the Federal University of Maranhão in Chapadinha.

Three soil samples with a deformed structure were removed in the layers of $0-0.1$ and $0.11-0.2 \mathrm{~m}$ from each of the four sample sites, generating two sets of six samples for each environment, which were homogenized to generate a composite sample for each environment. These samples were sent for physicalchemical characterization in the soil laboratory of the Federal University of Piauí / UFPI-Teresina (Table 1). 
The pluviometric data were obtained from the meteorological station of INMET (Instituto Nacional de Meteorologia).

Table 1: Physical and chemical characterization of the soils in the capoeira forest and gallery forest formations in the $0-$ 0.1 and 0.11-0.2 m layers, in an area of the Northeast Cerrado of the State of Maranhão, Brazil.

\begin{tabular}{|c|c|c|c|c|c|}
\hline Physical and chemical atttritutes & Units & $\begin{array}{l}\text { Capoeira Forest } \\
\mathbf{0 . 0 - 0 . 1} \mathbf{~ m}\end{array}$ & $\begin{array}{l}\text { Capoeira Forest } \\
\mathbf{0 . 1 1 - 0 . 2 ~} \mathbf{m}\end{array}$ & $\begin{array}{l}\text { Galery Forest } \\
\mathbf{0 . 0 - 0 . 1} \mathbf{~ m}\end{array}$ & $\begin{array}{l}\text { Galery Forest } \\
\mathbf{0 . 1 1}-\mathbf{0 . 2} \mathrm{m}\end{array}$ \\
\hline Sandy Coarse & g.kg-1 & 330 & 320 & 220 & 320 \\
\hline Sandy Fine & g.kg-1 & 400 & 380 & 410 & 410 \\
\hline Silt & g.kg-1 & 170 & 180 & 250 & 160 \\
\hline Clay & g.kg-1 & 100 & 120 & 120 & 110 \\
\hline$P$ & mg.kg-1 & 5 & 5 & 3 & 4 \\
\hline M.O. & g.kg-1 & 21 & 22.1 & 53.4 & 19.4 \\
\hline $\mathrm{Da}$ & g.cm-3 & 1.47 & 1.38 & 1.39 & 1.37 \\
\hline $\mathrm{pH} \mathrm{H} \mathrm{H}_{2} \mathrm{O}$ & - & 4.6 & 4.5 & 4.3 & 3.9 \\
\hline C.E. & $\mathrm{mS} . \mathrm{cm}-1$ & 0.1 & 0.1 & 0.3 & 0.1 \\
\hline $\mathrm{Na}^{+}$Saturation & cmolc.dm-3 & 1 & 1 & 4 & 2 \\
\hline $\mathrm{Ca}^{2+}$ & cmolc.dm-3 & 1.1 & 1.2 & 2.1 & 1.4 \\
\hline $\mathrm{Mg}^{2+}$ & cmolc.dm-3 & 0.4 & 0.9 & 0.02 & 1 \\
\hline $\mathrm{K}^{+}$ & cmolc.dm-3 & 0.09 & 0.06 & 0.07 & 0.05 \\
\hline $\mathrm{Na}^{+}$Saturation & cmolc.dm-3 & 0.4 & 0.07 & 0.31 & 0.18 \\
\hline $\mathrm{H}^{+}$ & cmolc.dm-3 & 4.5 & 3.6 & 5.8 & 5.3 \\
\hline $\mathrm{Al}^{3+}$ & cmolc.dm-3 & 0.3 & 0.5 & 0.5 & 1 \\
\hline Sat. $\mathrm{Al}^{3+}$ & cmolc.dm-3 & 15 & 19 & 28 & 28 \\
\hline$S$ & cmolc.dm-3 & 1.7 & 2.2 & 2.5 & 2.6 \\
\hline C.E.C. & cmolc.dm-3 & 6.5 & 6.3 & 8.8 & 8.9 \\
\hline V & $\%$ & 26 & 35 & 28 & 29 \\
\hline
\end{tabular}

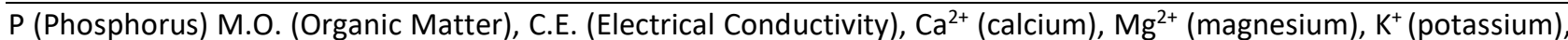
$\mathrm{Na}^{+}$(sodium), Sat. $\mathrm{Al}^{3+}$ (Aluminum Saturation), S (sum of exchangeable bases), C.E.C. (Cation Exchange Capacity), V\% (base saturation).

\section{Analyses}

Direct count data from the identified insect families was used to generate the ecological indexes: Shannon's diversity $H^{\prime}=\sum_{i=1}^{S} \frac{n i}{N} \cdot \ln \frac{n i}{N}$ and the equitability index of Pielou $J^{\prime}=\frac{H^{\prime}}{H \max }$ where $\mathrm{H} \max =\operatorname{Ln}(\mathrm{S})$, $\mathrm{S}=$ total number of families sampled, $\mathrm{N}=$ total number of individuals sampled, $\mathrm{ni}=$ number of individuals sampled for the $\mathrm{i}$-th family, and $\mathrm{Ln}=$ neperian logarithm. These indices were calculated using the Microsoft Office 365 Excel program. Data on the count of insect families per treatment were not normal, and the treatments were compared parametrically by the Kruskall Wallis test using the Software Infostat (CASANOVES et al., 2012).

\section{RESULTS}

Fifty-one insect families distributed in eight orders and one Collembola family, of the order Entomobrymorpha, family Entomobryidae, were identified. The largest number of families were found in the orders Diptera, Coleoptera, Hemiptera, and Hymenoptera. In these four orders, there were 44 of the 51 families identified in the four sampling sites (Table 2).

The most common families in the four sampling sites were registered in the orders Hymenoptera, Hemiptera, Coleoptera, Diptera, and Blataria. In these five orders, the most abundant families were Cicadelidae, Curculionidae, Crysomelidae, Dolichopodidae, Sciaridae, Tipulidae, Limoiidae, Ceratopogonidae, 
and Blatidae, while the least abundant were Melandryidae and Staphynilidae of the order Coleoptera, Ochteridae, Echteridaeidae, and Sphecidae in the order Hymenoptera, Gilhechidae and Tineidae in the order Lepidoptera, Ptiloneuridae in the order Psocoptera, and Entombryidae in the order Entomobrymorpha (Table 2).

Table 2: Families of insects with an immature phase in the soil collected in five sampling periods (P1, P2, P3, P4, and P5) and in four sampling sites (I - capoeria bush with serpilheira; II - bush forest without serpilheira, III - gallery forest with litter and IV - gallery forest without litter) in an area of the Northeast Cerrado of the State of Maranhão, Brazil.

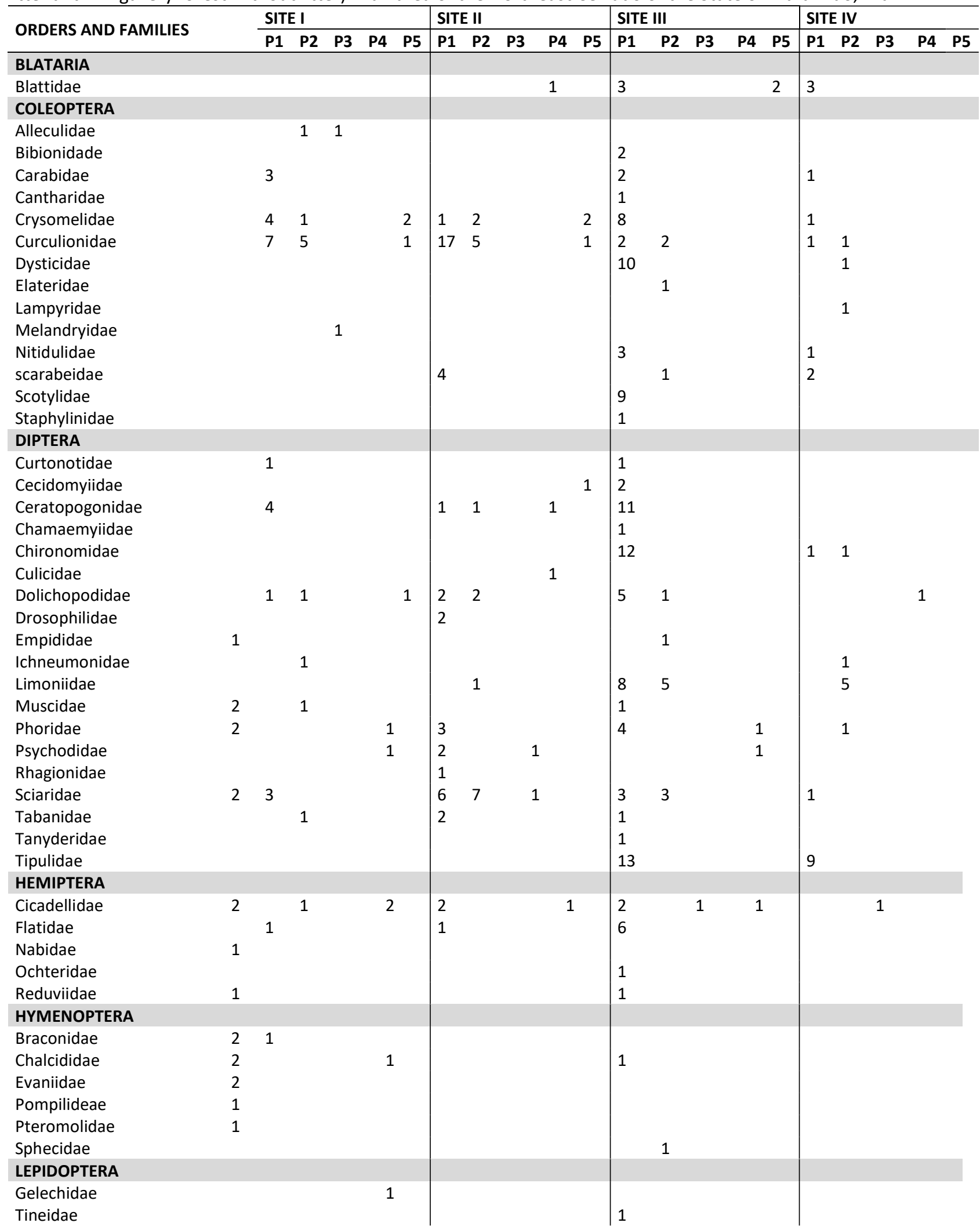




\begin{tabular}{|c|c|c|c|c|c|c|c|c|c|c|c|c|c|c|c|c|c|c|c|c|}
\hline \multicolumn{21}{|l|}{ ORTOPTERA } \\
\hline $\begin{array}{l}\text { Acrididae } \\
\text { Gryllidae }\end{array}$ & & & \multicolumn{3}{|l|}{1} & \multicolumn{5}{|l|}{1} & \multicolumn{5}{|l|}{$\begin{array}{l}4 \\
1\end{array}$} & \multicolumn{4}{|c|}{1} & 1 \\
\hline \multicolumn{21}{|l|}{ PSOCOPTERA } \\
\hline $\begin{array}{l}\text { Myopsocidae } \\
\text { Ptiloneuridae }\end{array}$ & $\begin{array}{l}2 \\
1\end{array}$ & & & & & & & & & & & & & & & & & & & \\
\hline \multicolumn{21}{|l|}{ COLLEMBOLA } \\
\hline Entombryidae & & 1 & & & & & & & & & & & & & & 1 & & & & \\
\hline TOTAL & 42 & 14 & 7 & 0 & 10 & 45 & 18 & 0 & 5 & 5 & 121 & 15 & 1 & 0 & 6 & 22 & 12 & 1 & 1 & 1 \\
\hline Diversity for Periodss $\left(H^{\prime}\right)$ & 3 & 2 & 1.9 & 0 & 2 & 2 & 2 & 0 & 2 & 1 & 3 & 2 & 0 & 0 & 2 & 2 & 2 & 0 & 0 & 0 \\
\hline Equitability for Periods $\left(J^{\prime}\right)$ & 1 & 1 & 1 & 0 & 1 & 1 & 1 & 0 & 1 & 1 & 0.6 & 1 & 0 & 0 & 1 & 1 & 1 & 0 & 0 & 0 \\
\hline Diversity for Sites $\left(H^{\prime}\right)$ & \multicolumn{5}{|c|}{3.02} & \multicolumn{5}{|c|}{2.26} & \multicolumn{5}{|l|}{3.17} & \multicolumn{5}{|c|}{2.62} \\
\hline Equitability for Sites $\left(J^{\prime}\right)$ & \multicolumn{5}{|c|}{0.70} & \multicolumn{5}{|c|}{0.53} & \multicolumn{5}{|c|}{0.64} & \multicolumn{5}{|c|}{0.73} \\
\hline
\end{tabular}

P1 - rainy season; P2 - rainy season / dry season transition; P3 - dry season; P4 - rainy season; P5 - rainy season / dry season transition, $H^{\prime}-$ Shannon's diversity, $J^{\prime}-$ Pielou equitability.

There were no statistical differences between the number of insect families found in the four sampling sites. Sites I, II, III, and IV were statistically equal (Kruskal-Wallis $\mathrm{H}=2$ and $p=1$; Table 3 ). Absolute data showed that sites I and II had the same number of individuals, 73 at each site distributed in 29 and 18 families, respectively. At sites III and IV, 143 and 37 individuals were found, respectively, distributed in 36 and 19 families at these two sites (Table 2). The number of individuals at site III was 3.8-fold greater than the number of individuals at site IV, which had 1.89-fold fewer families than site III.

Table 3: Analysis of variance (Kruskal-Wallis), families of insects sampled at Sites I (capoeira forest with litter), Site II (capoeira forest without litter), Site III (gallery forest with litter), and Site IV (gallery forest without litter) in an area of the Northeast Cerrado of the State of Maranhão, Brazil.

\begin{tabular}{lllllllll}
\hline Sites & N & Average & Standard Deviation & C.V & Median & H & p & Ranks \\
\hline & 19 & 5.05 & 8.23 & 61.36 & 2 & 2 & 1 & $42.42 \mathrm{~A}$ \\
II & 19 & 4.11 & 6.7 & 61.34 & 1 & & $38.58 \mathrm{~A}$ \\
III & 19 & 8.53 & 18.88 & 45.18 & 1 & $39.82 \mathrm{~A}$ \\
IV & 19 & 2.42 & 5.43 & 44.56 & 0 & $33.18 \mathrm{~A}$ \\
\hline
\end{tabular}

C.V.coefficient of variation.

The families Evaneidae, Ptloneruridae, Alleculidae, and Melandryidae were found only at Site I. Rhagionidae and Culicidae were registered at Site II, Scotilidae, Tanyderidae, Bibionidae, Sphecidae, Elateridae, and Empididae at Site III, and Lampyridae only at Site IV.Bibionidae, Curculionidae, Dysticidae, Tipulidae, Escarabeidae, and Chironomidae were found in sites I, II, III, and at the site IV Carabidae and Phoridae (Table 2).

The number of families and individuals sampled in the first collection period was statistically higher than in the other collection periods (Table 2). These differences were observed at all sampling sites, especially at sites I and III, where the litter layer was preserved. (Table 2). Dolichopodidae and Curculionidae families were found only in collection periods P1 and P2. The family Sciaridae was registered in periods P1, P2, and P4 and individuals of the family Tipulidae occurred only in period (P1) of sites III and IV.The first period of collection was climatologically classified in the study region as rainy winter, which accumulated about 1000 $\mathrm{mm}$ of rain Figure 2 .

In the following periods, the number of insect families was similar, with no differences between periods of drought, rain, and the transition periods between these seasons. Periods P4 and P5 corresponded to the rainy season of the second year of collection, when $1942 \mathrm{~mm}$ of accumulated precipitation was 
recorded (Figure 2). Variation in the amount of rain in 2010 for 2011 affected the soil moisture. During the rainy season, humidity rises but decreases dramatically during the dry season. The volume of water in the soil in the first rainy period (January to July 2010) was less than the volume of water in the second rainy period (January to June 2011). The temperature did not show significant variations during the collection period, remaining around $30^{\circ} \mathrm{C}$.

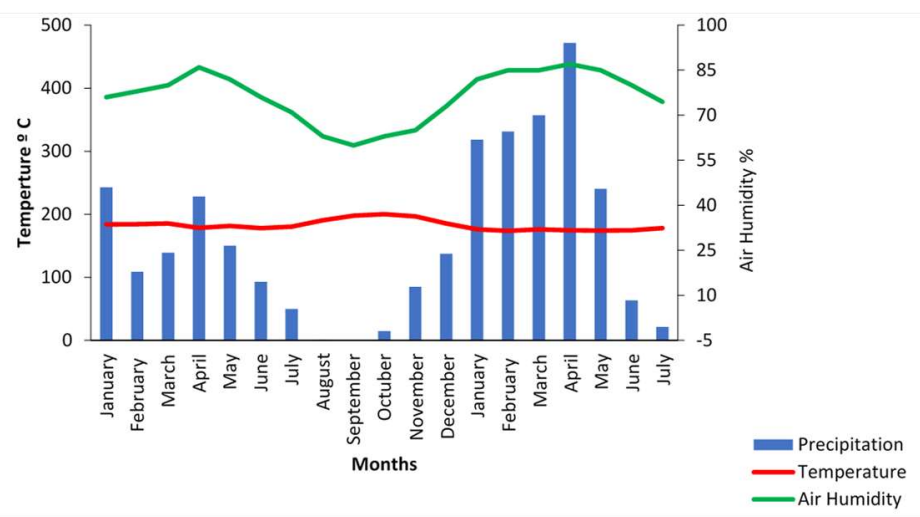

Figure 2: Temperature, atmospheric humidity, and accumulated precipitation in an area of Cerrado located in the Northeast of Brazil in the period from January 2010 to June 2011.

The soil at sites I and II are sandy, with lower levels of organic matter, less potential for water retention, denser, poor in nutrients, and more acidic when compared to the soil at sites III and IV.In these last two sites, the hydromorphic conditions of the soil due to the superficialization of the water table stands out. The granulometry of these soils rich in clay and silt and the high teors of organic matter keep these soils saturated even in the dry season (Table 1).

The equitability indices (Table 2) show uniformity above $50 \%$ for the communities of winged insects with an immature phase in the soils at the four sampled sites. Shannon's diversity indices were similar at sites I and III, where the litter layers were preserved. The diversity indices at these sites were 3.02 and 3.17, being higher than the values obtained in the places where the litter layers were removed (sites II and IV), which registered 2.26 and 2.62, respectively. The differences between these ecological indices were treated considering the absolute values, therefore, they were not statistically validated, since the nonparametric comparison of these data by the Kruskal-Wallis test did not mark these differences $(H=1.32 p=0.67)$. The diversity and equitability indices of the first sampling period at all four sites was higher than the values obtained for the other sampling periods (Table 2), being equivalent to the sum of these indices obtained at each sampling site (Table 2).

\section{DISCUSSION}

The expressive number of insect families collected in this study was greater than the records obtained for this same taxonomic group in the biomes adjacent to the study area, as shown by the data obtained in the Caatinga by Azevedo et al. (2011). The specificity of the collection method used in this study, which includes only the insects that nest in the soil or in the litter, more strongly validates the differences between the number of insect families obtained in this study in relation to other studies with families of insects 
collected in the Cerrado biome and surroundings, adopting more than one collection method (CAJAIBA et al., 2015; AZEVEDO et al., 2016; POMPEO et al., 2016; GUEDES et al., 2019). The greater number of taxa in the study area was supported by the ecotonal peculiarity of the region, which borders the Pre-Amazon and Caatinga. Ecotonal zones accumulate a greater number of species (BEGON et al., 2007; RICKLEFS, 2010), mainly of insects, which constitute the group of edaphic invertebrates most frequently found in the soil (LEIVAS et al., 2008). In these ecotonal regions, insects encounter pedoclimatic conditions that favor development (MORRONE, 2006; TURNEY et al., 2018; LIMA et al., 2020a). This premise of greater diversity in ecotonal zones is permissible even in regions that tend to aridity, as was the study area of this study and in arid regions, as highlighted by SALOMÃO et al. (2019).

The dominance of individuals of the orders Diptera, Coleoptera, Hymenoptera, and Hemiptera in the studied soils would not be uncommon, given that these orders are composed of insects with indirect development, which find the soil a favorable substrate for the development of intermediate phases (ROSA et al., 2015; POMPEO et al., 2016). Soil is a substrate rich in refuges and resources necessary for the development of intermediate phases of many animals, mainly insects (DUAN et al. 2019; YANG et al., 2020), especially for those with immature phases that develop in the soil.

The quantitative data obtained for families of insects with an immature phase in the soil in this study area cannot be directly compared with studies of similar environments because there are no studies of this nature in regions of the Cerrado of Brazil, especially in ecotonal areas. Similar studies using the same method were conducted in the Amazon by Alencar (2007) and the Atlantic Forest by Casanova (2001) with the purpose of capturing sandflies. These authors used emergency traps to capture Psychodidae and collected 6 to 8 times more individuals than that collected for this family in this study, showing that the phytophysiognomies and edaphoclimatic conditions of the studied Cerrado were not favorable for the development of these insects. When emergency traps were installed in the peridomicile by Casanova (2001), the number of captured phlebotomines was increased, as these environments accumulate favorable conditions for the development of these insects with a rich supply of substrates, shelter, and food for the development of larval and adult phases (XIMENES et al., 2007). Silva et al. (2010) confirmed the high adaptability of Psychodidae to the peridomillar environments, especially the vector species of tropical diseases belonging to the genus Lutzomya.

The collection traps used in this study were not efficient to sample all the variations in the surfaces of the studied soils. It was not possible, for example, to adjust the base of the trap squares to the basal circumferences of tree trunks and termite mounds frequently used for nesting insects of the Pompilidae (SZCZEPKO et al., 2020) and Sphecidae families that build nests in dry, sandy soils, on dead trunks deposited on the ground (OLIVEIRA et al., 2020).

The small number of insect families of the order Lepdoptera was due to the prevalent presence of immature forms of these insects in fruits, seeds, and other substrates outside the soil (AZEVEDO et al., 2016). Pscoptera and Colembola had a low frequency in this study because the collection method used was not appropriate for sampling insects of these orders, which are usually collected with the aid of a Berlese funnel 
(SANTOS et al., 2016).

The most frequent insect families in this study were in the dominant orders in the study environments, such as the Curculionidae and Crysomelidae families of the order Coleoptera that are frequently found in soil (LINZMEIER et al., 2006; CAJAIBA et al., 2015) and in the families of insects of the order Diptera that are also recurrent in the pedological environment (BENEFER et al., 2016) with emphasis on the mosquitoes of families Sciaridae, Tipulidae, Limoniidae, and Ceratopogonidae.

The prevalence of Cicadelliade of the order Hemiptera is typical in environments with greater expression of aridity, such as the Cerrado of the study area, especially in the capoeira forest phytophysiognomies (sites I and II) where these insects were sampled in greater number, corroborating the observations of Azevedo et al. (2011) and Creão-Duarte et al. (2012) that present the Cicadellidae as a family of insects with accessory species in the Brazilian caatinga. Azevedo et al. (2015) reiterated the strong association of Cicadellidaes with arid and anthropized environments. According to these authors, these environments favor the aerial displacement of these insects and offer a greater supply of substrates and resources more easily accessible to phytophages in this family.

Insects of the families Grilidae and Cynidae found in sites I and II of the capoeira forest are frequently found in phytophysiognomies of dry forests, where there are low levels of humidity and a reduced volume of litter, as verified by Azevedo et al. (2016) for insects from these same families. In the xerophytic conditions of dry forests, the insects of these families lay eggs in the subsurface layers of the soil, sheltering them from the effects of desiccation and dehydration (JAWORSKI et al., 2013). From the physical attributes to the chemical attributes of the soil, there is a wide spectrum of variables correlated to the population dynamics of the edaphic macrofauna (ROSA et al., 2015). Soil insects integrate and interact with soils, modifying the pedological environment and producing favorable conditions for colonization.even of arid soils, as do insects of the Grilidae family that alter the thermal and humidity conditions of dry soils, mobilizing organic matter to keep these soils moist (YANG et al., 2020), guaranteeing them the necessary humidity and temperature conditions for the development of edaphic insects (LEPAGE et al., 2012). In the savannah, soils with physical and chemical attributes appropriate to the production and maintenance of aerated pedological microenvironments and lower temperatures produce rich and abundant soil substrates in adult and immature insect species adapted to these environments, mainly families of Sacarabeidae, Staphyilinade (POMPEO et al., 2016) and Hymenoptera-Formicidae (SILVA et al., 2017; LIMA et al. 2020b).

The greater abundance of samples in the first collection period shows the effects of high levels of water in the soil, affecting the community of edaphic organisms. Edaphic insects are not abundant in saturated and unsaturated water soils. Intermediate water levels favor amplification of the richness and abundance of insects in the soil, as observed in this study and by Zagatto et al. (2020), who observed a strong correlation of average water content in the soil with an abundance of edaphic insects. Soils in these conditions of humidity and porosity have appropriate proportions of porous space for aeration and water retention (POMPEO et al., 2016). However, there are many groups of insects and other soil invertebrates dependent on varying levels of soil moisture (CAMARA et al., 2019), with some very successful groups in 
humid to hydromorphic soils, such as insects of the family Sciaridae of the order Diptera and insects of the family Dysticidae of the order Coleoptera (BORROR et al., 2005; AZEVEDO et al., 2016). However, the families of Coleoptera (Aleculidade, Crysomelidae and Curculionidae) and Diptera (Phoridae and Dolichopodidae) are not viable in soils saturated with water, needing water only to avoid the effects of desiccation and dehydration at different stages of development (JAWORSKI et al., 2013; VISSER et al., 2018).

Temperature was not an unstable variable during the observation periods. The proximity of the study area to the Equator keeps the temperature in very stable ranges during the different seasons. The most significant thermal variations occur between daytime and nighttime, often with gradients close to $15^{\circ} \mathrm{C}$ between the maximum temperatures recorded during the day and the minimum recorded at night (NOGUEIRA et al., 2012). Therefore, the variation occurs between night and day shifts but remains stable during those shifts. Thermal stability in day and night shifts reduces the stress of environmental factors on the insect community of this region, mainly for immature forms that live in the soil, where this substrate naturally reduces and/or neutralizes the effects of thermal variations that affect this group of arthropods sensitive to changes in temperature and humidity (LUCIA et al., 2012).

The removal of the litter layer at sites II (capoeira forest) and IV (gallery forest) did not change the temperature significantly; this was most likely because the cover and shading of the trap itself had mitigated the effects of sunlight on the soil in these treatments. The litter minimizes the local temperature as it is a labile source of trophic resources and mainly a source of refuge for insects residing in this stratum (Silva et al., 2020), in the subsurface layers of soils where the physical and chemical attributes of the soils define optimal pedoecological rules that govern the taxonomic and ecological dynamics of life on the ground (ROSA et al., 2015, POMPEO et al., 2016) and above-ground (LEPAGE et al., 2012), where they are subject to the effects of vegetation cover and climatological factors.

The predominantly xerophytic climatology of the Cerrados, especially in the central and northeast regions of Brazil, contrasts with the formations of wet forests found on the edges of rivers and springs of this biome. The edaphic fauna of these environments is predominantly composed of insects of the order Coleoptera (AZEVEDO et al., 2016), adapted to soils saturated with water and suitable for the development of aquatic larval phases, such as beetles of the family Dityscidae, which can be found in the adult phase even in xeric environments, as long as there are hydromorphic environments in the surrounding area (GUEDES et al., 2019). The occurrence of insects of the Carabidae and Phoridae families in the four sample sites showed that these insects are possibly affected by other factors that were not evaluated in this study, or this may confirm the resilience and high adaptability of these insects to extreme environments, such as the family fly larvae. Phoridae can be found in a wide range of substrates (BORROR et al., 2005). The beetles of the Carabidae family (AZEVEDO et al., 2016) are known for the diversity of substrates that they use for nesting, as well as the Phoridae flies (BORROR et al., 2005) that lay eggs in decomposing animal and vegetable tissues, oviposit in other insects, and may also use termite nests.

The diversity indices obtained in all treatments in this study were considered high, even those obtained in treatments where the litter layer was removed: site II - Capoeira forest and site IV - Gallery forest. 
Diversity indices from 2.26 to 3.17 must be seriously observed, as the collection method adopted in this study only sampled part of the insect community of tropical dry forests, where the expected diversity indices, according to Wulandari et al. (2018), should be close to 1 . The diversity indices observed for families of insects with an immature phase in the studied soils may reflect the diversity of this community at lower taxonomic levels, since indices of diversity of insect families can be used as predictors of the diversity of species (ZOU et al., 2020). However, there are factors that can affect these prediction models, and in the specific case of sites I and III, the maintenance of the litter layer increased the diversity by $30 \%$ and $20 \%$, respectively.

The highest levels of diversity recorded at sites I (capoeira forest, with litter) and III (gallery forest with litter) shows the relevance of litter in the composition and maintenance of soil diversity. The litter layer forms an environment with thermal and humidity conditions favorable to the development of epigeic and endogenous organisms, in addition to providing them with large stocks of food and microrefuge as highlighted (BORGES et al., 2019; PESSOTTO et al., 2020). In these terms, it is possible to think of the litter composing one of the layers of the pedological horizon, forming an appropriate environment for the development of insects in immature stages and for other organisms that have a complete life cycle in this environment, such as the Collembola mentioned by Borges et al. (2019).

At sites I and II with and without litter, located in the capoeira forest, the difference between the diversity indices and the similarity of the abundance data reiterates the effect of litter on the composition of more diversified, equitable, rich, and abundant families. At sites III and IV of the gallery forest, the removal of the litter layer significantly affected the results obtained. In these two environments, insects used litter as a nesting substrate. The use of litter as a nesting substrate is mainly due to the hydromorphic condition of soils in environments III and IV.In site IV, where the litter was removed, there were families of insects with larval stage adapted to water saturated environments, such as beetles of the family Dysticidae.

Site IV had appropriate humidity and temperature conditions for recording higher values of diversity, as humid and forested environments are rich and abundant in insects (JAWORSKI et al., 2013; LOPES et al., 2017). However, this did not happen because the soils on this site were saturated with water, causing most of the immature community in these environments to develop in the litter, and as the litter layer in this place was removed, this reduced the wealth and abundance of insects in that area site, where the dominant families were those of insects with immature phases adapted to anoxic and saturated soils with water (AZEVEDO et al., 2016; MBOYE et al., 2018). These environments limit the development of many insect species with a larval stage in the soil (VISSER et al., 2018) but species tolerant to anoxic conditions are abundant in these soils.

\section{CONCLUSIONS}

This study presents a high number of insect families with an immature phase in the soil, while the majority researches with the soil organisms involve Dipteras of the Culicidae's family. In this study, the community of winged insects with an immature phase in the soil was quite diversified. The diversity rates were higher in the sample sites where the litter layer was preserved. The number of insect families sampled 
was affected by climatic seasonality. The spatial variation did not affect the number of insect families collected in the four sampling environments.

ACKNOWLEDGEMENTS: To the Laboratory of Medical Entomology of the CCAA, Center for Agrarian and Environmental Sciences of UFMA, and the National Health Foundation FUNASA- Chapadinha for the availability of materials and identification equipment for identification of the samples. This study was financed in part by the Coordenação de Aperfeiçoamento de Pessoa de Nível Superior - Brasil (CAPES) Finance Code 001, and and by Fundação Maranhense de Apoio à Pesquisa Científica e ao Desenvolvimento Tecnológico (FAPEMA).

\section{REFERENCES}

ALENCAR, R. B.. Emergência de flebotomíneos (Díptera: Psychodidae) em chão de floresta de terra firme na Amazônia Central do Brasil: Uso de um modelo modificado de armadilha de emergência. Acta Amazônica, v.37, n.2, p.287-292, 2007.

AZEVEDO, F. R.; AZEVEDO, R.; MOURA, E. S.; SANTOS, C. A. M.. Inventário da entomofauna de ecossistemas da Área de Proteção Ambiental do Araripe com bandejas d'água amarelas. HOLOS, v.3, p.121-134, 2015. DOI: http://dx.doi.org/10.15628/holos.2015.2249

AZEVEDO, F. R.; MOURA, M. A. R.; ARRAIS, M. S. B.; NERE, D. R.. Composição da entomofauna da Floresta Nacional do Araripe em diferentes vegetações e estações do ano. Revista Ceres, v.58, n.6, p.740-748, 2011.

AZEVEDO, F. R.; AZEVEDO, R.; SANTOS, C. A. M.; NERE, D. R.; MOURA, E. S.. Análise faunística e sazonalidade de insetos edáficos em ecossistemas da Área de Proteção Ambiental do Araripe em duas estações do ano, Barbalha-CE. Revista Agro@mbiente On-line, v.10, n.3, p.263-272, 2016. DOI: http://dx.doi.org/10.18227/1982-8470ragro.v10i3.2910

BAPTISTA, V. A.; ANTUNES, M. B.; MARTELLO, A. R.; FIGUEIREDO, N. S. B.; AMARAL, A. M. B., SECRETTI, E.; BRAUN, B.. Influência de fatores ambientais na distribuição de famílias de insetos aquáticos em rios no sul do Brasil. Ambiente \& Sociedade, v.17, n.3, p.155-176, 2014. DOI: http://dx.doi.org/10.1590/S1414-753X2014000300010

BEGON, M.; TOWNSEND, C. R.; HARPER, J. L.. Ecologia de Indivíduos a Ecossistemas. Porto Alegre: Artmed, 2007.

BENEFER, C. M.; D'AHMED, K.; BLACKSHAW, R. P.; SINT, H. M.; MURRAY, P. J.. The Distribution of Soil Insects across Three Spatial Scales in Agricultural Grassland. Frontiers and Ecology and Evolution, v.4, p.1-9, 2016. DOI: http://dx.doi.org/10.3389/fevo.2016.00041

BORGES, C. H. A.; SOUTO, J. S.; SILVA, A. C. F.; ALENCAR, L. S.; LIMEIRA, M. Q. R.; SANTOS, A. C.; SOUTO, L. S.; SOUTO, P. C.. Edaphic Arthropods in Fragment of Riparian Forest in the Semi-Arid of Paraíba. Journal of Agricultural Science, v.11, n.2, p.236-243, 2019. DOI:

http://dx.doi.org/10.5539/jas.v11n2p236
BORROR, D. J.; DELONG, D. M.. Introduction to the Study of Insects. 7 ed. Thomson Brooks, 2005.

CAJAIBA, R. L.; SILVA, W. B.. Abundância e Diversidade de Coleoptera (Arthropoda: Insecta) de Solo em Fragmentos de Capoeira ao Entorno da Zona Urbana do Município de Uruará-PA, Brasil. EntomoBrasilis, v.8, n.1, p.30-37, 2015. DOI: http://dx.doi.org/10.12741/ebrasilis.v8i1.414

CAJAIBA, R. L.; SILVA, W. B.. Diversidade e sazonalidade de Cydnidae (Insecta: Hemiptera: Heteroptera) em diferentes habitats no estado do Pará, norte do Brasil. Revista Brasileira de Biociências, v.15, n.1, p.32-37, 2017.

CAMARA, R.; SILVA, C.; SANTOS, G.; AGUIAR, G.; PEREIRA, M.; SILVA, C.; SILVA, E.. Physical, chemical, and biological soil attributes under analog agroforestry system and pasture sites. Floresta, v.50, n.1, p.887-896, 2019. DOI: http://dx.doi.org/10.5380/rf.v50i1.57476

CASANOVA, C.. A Soil Emergence Trap for Collections of Phlebotomine Sand Flies. Memórias do Instituto Oswaldo Cruz, v.96, n.2, p.273-275, 2001.

CASANOVES, F.; DI RIENZO, J. A.; BALZARINI, M. G.; GONZALEZ, L.; TABLADA, M.; ROBLEDO, C. W.. InfoStat. User Manual. Córdoba, 2012

CORREA, M. E. F.; OLIVEIRA, L. C. M.. Fauna de Solo: Aspectos Gerais e Metodológicos. Seropédica: Embrapa Agrobiologia, 2000.

CREÃO-DUARTE, A. J.; ANJOS, U. U.; SANTOS, W. E. Diversidade de membracídeos (Hemiptera, Membracidae) e sobreposição de recursos tróficos em área do semi-árido. Iheringia, Série Zoologia, v.102, n.4, p.453-458, 2012.

CULVER, D. C.; PIPAN, T.. Insects in Caves. In Insect Biodiversity (eds R.G. Foottit and P.H. Adler). 2018. DOI: http://doi.org/10.1002/9781118945582.ch6

DUAN, C.; JIANG, X. H.; CHANG, Q. Q.; HOU, X. H.. First description of the immature stages of Dasyhelea alulaand a redescription of adults from China (Diptera, Ceratopogonidae). ZooKeys, v.824, p.135-145, 2019. DOI: http://dx.doi.org/10.3897/zookeys.824.31722 
FOURCADE, Y.; RANIUS, T.; ÖCKINGER, E.. Temperature drives abundance fluctuations, but spatial dynamics is constrained by landscape configuration: Implications for climate-driven range shift in a butterfly. Journal of Animal Ecology, v.86, p.1339-1351, 2017. DOI: http://dx.doi.org/10.1111/1365-2656.12740

GUEDES, R. S.; ZANELLA, F. C. V.; GROSSI, P. C.. Composição e riqueza de espécies de uma comunidade de Coleoptera (Insecta) na Caatinga. Iheringia, Série Zoológica, v.109, p.114, 2019. DOI: http://dx.doi.org/10.1590/16784766e2019012

JAWORSKI, T.; HILSZCZAŃSKI, J.. The effect of temperature and humidity changes on insects development their impact on forest ecosystems in the expected climate change. Forest Research Papers, v.74, n.4, p.345-355, 2013. DOI: http://dx.doi.org/10.2478/frp-2013-0033

LEIVAS, F. W. T.; FISCHER, M. L.. Avaliação da Composição de Invertebrados Terrestre em área rural localizada no município de Campina Grande do Sul Paraná Brasil. Biotemas. v.21, n.1, p.65-73, 2008.

LEPAGE, M. P.; BOURGEOIS, G.; BRODEUR, J.; BOIVIN, G. Effect of Soil Temperature and Moisture on Survival of Eggs and First-Instar Larvae of Delia radicum. Environmental Entomology, v.41, n.1, p.159-165, 2012. DOI: http://dx.doi.org/10.1603/EN10313

LIMA, C. S.; DALZOCHIO, M. S.; SILVA, E. F.; PÉRICO, E.. Composição funcional e sazonalidade da macrofauna edáfica em diferentes usos do solo, Bioma Cerrado, Brasil. Revista Ibero Americana de Ciências Ambientais, v.11, n.6, p.33-48, 2020a. DOI: http://doi.org/10.6008/CBPC21796858.2020.006.0004

LIMA, C. S.; DALZOCHIO, M. S.; SILVA, E. F.; PÉRICO, E.. Macrofauna edáfica e sua relação com sazonalidade em sistema de uso do solo, bioma cerrado. Revista Ibero Americana de Ciências Ambientais, v.11, n.2, p.1-13, $2020 \mathrm{~b}$. DOI: http://doi.org/10.6008/CBPC2179-6858.2020.002.0001

LINZMEIER, A. M.; COSTA, C. R. S.; MARINONI, R. C.. Fauna de Alticini (Newman) (Coleoptera, Chrysomelidae, Galerucinae) em diferentes estágios sucessionais na Floresta com Araucária do Paraná, Brasil: diversidade e estimativa de riqueza de espécies. Revista Brasileira de Entomologia, v.50, n.1, p.101-109, 2006.

LOPES, A. S.; SOARES, S.; SILVA, E. M.; ROEL, A. R. Diversidade de insetos e aranhas presentes em diferentes fisionomias no Pantanal, na seca e cheia, Corumbá, MS. Multitemas, v.22, n.51, p.127-154, 2017. Dol: http://dx.doi.org/10.20435/multi.v22i51.1422

LUCIA, E. H.; NABITY, P. D.; ZAVALA, J. A.; BERENBAUM, M. R.. Climate change: Resetting Plant-Insect Interactions. Plant Physiology, v.160, n.4, p.1677-1685, 2012. DOI: http://dx.doi.org/10.1104/pp.112.204750

MAESTRI, R.; LEITE, M. A. S.; SCHMITT, L. Z.; RESTELLO, R. M. Efeito de mata nativa e bosque de Eucalipto sobre a riqueza de artrópodos na serapilheira. Revista Perspectiva, v.37, p.31-40, 2013.

MBOYE, B. R.; MENBOHAN, S. F.; MBEGA, J. D.; BIRAM À
NGON, E. B.. Influence of the granulometric parameters on the diversity and distribution of benthic macroinvertebrates in the Mabounié Watershed (Central West Gabon). International Journal of Advanced Research in Biological Sciences, v.5, n.7, p.252-270, 2018. DOI: http://dx.doi.org/10.22192/ijarbs.2018.05.07.020

MCCOLLOCH, J. W.; RYES, W. P.. The Reciprocal Relation of Soil and Insects. Ecology, v.3, n.4, p.288-301, 1992.

MERLIM, A. O.; AQUINO, A. M.; CARDOSO, E. J.. Larvas de Coleópteras em ecossistemas no Parque Estadual de Campos do Jordão, SP. Ciência Rural, v.36, n.4, p.1303-1306, 2006.

MORRONE, J. J.. Biogeographic areas and transition zones of Latin America and the Caribbean islands based on panbiogeographic and cladistic analyses of the entomofauna. Annual Review Entomology, v.51, p.467-494, 2006. DOI:

http://dx.doi.org/10.1146/annurev.ento.50.071803.130447

NOGUEIRA, V. F. B.; CORREIA, M. F.; NOGUEIRA, V. S.. Impacto do Plantio de Soja e do Oceano Pacífico Equatorial na Precipitação e Temperatura na Cidade de Chapadinha/MA. Revista Brasileira de Geografia Fisica, v.3, p.708-724, 2012.

OLIVEIRA, G. K. C.; ELIAS, M. A. S.; BERGAMINI, L. L.; FRANCESCHINELLI, E. V.. Reproductive success of Trypoxylon (Trypargilum) lactitarse (Hymenoptera: Crabronidae) in a fragmented landscape. Iheringia, Série Zoolóogica, v.110, p.1-8, 2020. DOI: http://dx.doi.org/10.1590/16784766e2020004

OLIVEIRA, L. J.; MALGUIDO, A. B.. Flutuação e Distribuição Vertical da População do Percevejo Castanho da Raiz, Scaptocoris castanea Perty (Hemiptera: Cydnidae), no Perfil do Solo em Áreas Produtoras de Soja nas Regiões CentroOeste e Sudeste do Brasil. Neotropical Entomology, v.33, n.3, p.283-291, 2004. DOI: http://dx.doi.org/10.1590/S1519566×2004000300002

PESSOTTO, M. D. F.; SANTANA, N. A.; JACQUES, R. J. S.; FREIBERG, J. A.; MACHADO, D. N.; PIAZZA, E. M.; ROSA NETO, L.; ANTONIOLLI, Z. I.. Relação do uso do solo com a diversidade e a atividade da fauna edáfica. Nativa, v.8, n.3, p.397-402, 2020. Dol:

http://dx.doi.org/10.31413/nativa.v8i3.9769

POMPEO, P. N.; OLIVEIRA FILHO, L. C. I.; KLAUBERG FILHO, O.; MAFRA, Á. L.; BARETTA, C. R. D. M.; BARETTA, D.. Diversidade de Coleoptera (Arthropoda: Insecta) e atributos edáficos em sistemas de uso do solo no Planalto Catarinense. Revista Scientia Agraria, v.17, n.1, p.16-28, 2016.

RICKLEFS, R. E.. Economia da Natureza. 6 ed. Rio de Janeiro: Guanabara Koogan, 2010.

RIIS, L.; ESBJERG, P.. Season and Soil Moisture Effect on Movement, Survival, and Distribution of Cyrtomenus bergi (Hemiptera: Cydnidae) within the Soil Profile. Environmental Entomology, v.27, n.5, p.1182-1189, 1998. DOI: http://dx.doi.org/10.1093/ee/27.5.1182

RIIS, L.; ESBJERG, P.; BELLOTTI, A. C.. Influence of Temperature and Soil Moisture on Some Population Growth Parameters of Cyrtomenus bergi (Hemiptera: Cydnidae). 
Florida Entomologist, v.88, n.1, p.11-22, 2005.

ROBINSON, S. I.; MCLAUGHLIN, Ó. B.; MARTEINSDÓTTIR, B.; O'GORMAN, E. J.. Soil temperature effects on the structure and diversity of plant and invertebrate communities in a natural warming experiment. Journal of Animal Ecology, v.87, p.634-646, 2018. DOI: http://dx.doi.org/10.1111/13652656.12798

ROSA, M. G.; KLAUBERG FILHO, O.; BARTZ, M. L. C.; MAFRA, A. L.; SOUSA, J. P. F. A.; BARETTA, D.. Macrofauna Edáfica e Atributos Físicos e Químicos em Sistemas de Uso do Solo no Planalto Catarinense. Revista Brasileira de Ciência do Solo, v.39, n.6, p.1544-1553, 2015. DOI: http://dx.doi.org/10.1590/01000683rbcs20150033

SALOMÃO, R. P.; GONÇALVES, L. K. S.; MORAIS, R. F.; LIMA, L. R. C.. Dung beetles (Coleoptera: Scarabaeinae) in a mosaic habitat at the ecotone between two savanna ecosystems in the Neotropical region. International Journal of Tropical Insect Science, v.39, p.249-256, 2019. DOI: http://dx.doi.org/10.1007/s42690-019-00031-8

SANTOS, G. R.; SILVA, A. B.; CORREIA, A. N. C. L.; VILELA, S. L. S.; ARAUJO, K. D.. Invertebrados da macrofauna e mesofauna do solo em ambiente de caatinga arbóreoarbustiva, em Santana do Ipanema, Semiárido Alagoano. Revista de Geociências do Nordeste, v.2, p.894-903, 2016.

SEFFRIN, R. C. D.; COSTA, E. C.; DEQUECH, S. T. B. Artropodofauna do solo em sistemas direto e convencional de cultivo de Sorgo (Sorghum bicolor (L) Moech) na região de Santa Maria, RS. Ciência e Agrotecnologia, v.30, n.4, p.597-602, 2006.

SHEIKH, A. A.; REHMAN, N. Z.; KUM, R.. Diverse adaptations in insects: a review. Journal of Entomology and Zoology Studies, v.5, n.2, p.343-350, 2017.

SILVA, D. C.; PEREIRA, J. M.; ORTIZ, D. C.; OLIVEIRA FILHO, L. C. I.; PINTO, L. V. A.. Fauna edáfica como indicadora de qualidade do solo em fragmentos florestais e área sob cultivo do cafeeiro. Brazilian Journal of Development, v.6, n.3, p.14795-14816, 2020.

SILVA, E. F.; CORÁ, J. E.; HARADA, A. Y.; SAMPAIO, I. B. M.. Association of the occurrence of ant species (Hymenoptera: Formicidae) with soil attributes, vegetation, and climate in the Brazilian Savanna northeastern region. Sociobiology, v.64, n.4, p.442-450, 2017. DOI:

http://dx.doi.org/10.13102/sociobiology.v.64i4.1209

SILVA, F. S.; CARVALHO, L. P. C.; CARDOZO, F. P.; MORAES, J. L. P.; REBÊLO, J. M. M.. Sand flies (Diptera: Psychodidae) in a cerrado area of the Maranhão state, Brazil. Neotropical Entomology, v.39, n.6, p.1032-1038, 2010.

SZCZEPKO, K.; KRUK, A.; WIŚNIOWSKI, B.. Local habitat conditions shaping the assemblages of vespid wasps (Hymenoptera: Vespidae) in a post-agricultural landscape of the Kampinos National Park in Poland. Scientific Reports, v.10, n.1424, p.1-16, 2020. DOI:

http://dx.doi.org/10.1038/s41598-020-57426-8

TURNEY, S.; ALTSHULER, I.; WHITE, L. G.; BUDDLE, C. M.. Macroinvertebrate andsoil prokaryote communities in the forest-tundra ecotone of the Subarctic Yukon.Polar Biology, v.41, p.1619-1633, 2018. DOI:

http://dx.doi.org/10.1007/s00300-018-2330-5

URBINATTI, P. R.; SENDACZ, S.; NATAL, D.. Imaturos de mosquitos (Diptera:Culicidae) em parque de área metropolitana aberto à visitação pública. Revista Saúde Pública, v.35, n.5, p.461-466, 2001.

VISSER, B.; WILLIAMS, C. M.; HAHN, D. A.; SHORT, C. A.; MARTINZE, G. L.. Hormetic benefits of prior anoxia exposure in buffering anoxia stress in a soil-pupating insect. Journal of Experimental Biology, v.221, p.1-9, 2018. DOI: http://dx.doi.org/10.1242/jeb.167825

WULANDARI, A. D.; INDRAWATI, T.; MAGHFIRAH, F. F.; SARI, E. K. A. P.; ROSMANIDA, S. F.. Diversity of Soil Macro Insect in Alas Purwo National Park, Banyuwangi, East Java, Indonesia. Journal of Tropical Biodiversity and Biotechnology, v.3, n.2, p.62-66, 2018. DOI: http://dx.doi.org/10.22146/jtbb.33773

XIMENES, M. F. F.; SILVA, V. P. M.; QUEIROZ, P. V. S.; REGO, M. M.; CORTEZ, A. L. M.; BATISTA, L. M. M.; MEDEIROS, A. S.; JERONIMO, S. M. B.. Flebotomíneos (Diptera: Psychodidae) e Leishmanioses no Rio Grande do Norte, Nordeste do Brasil: Reflexos do Ambiente Antrópico. Neotropical Entomology, v.36, n.1, p.128-137, 2007.

YANG, X.; SHAO, M.; LI, T.; JIA, Y.; JIA, X.; HUANG, L.. A preliminary investigation of the effect of mole cricket (Gryllotalpa unispina Saussure; Orthoptera: Gryllotalpidae) activity on soil evaporation in semiarid Loess Plateau of northwest China. Geoderma, v.363, p.114-144, 2020. DOI: http://dx.doi.org/10.1016/j.geoderma.2019.114144

ZAGATTO, M. R. G.; OLIVEIRA FILHO, L. C. I.; POMPEO, P. N.; NIVA, C. C.; BARETTA, D.; BRAN, N. C. E. J.. Mesofauna and Macrofauna in Soil and Litter of Mixed Plantations. In: BRAN, N. C. E.; GONÇALVES, J.; BALIEIRO, F.; FRANCO, A.. Mixed Plantations of Eucalyptus and Leguminous Trees. Cham: Springer, 2020. DOI: http://dx.doi.org/10.1007/978-3-03032365-3-8

ZIMMER, C. R.; PIRES, S. M.; CÁRCAMO, M. C.; RIBEIRO, P. B.. Efeitos da competição larval intra-específica sobre caracteres biométricos de Muscinastabulans (Fallén, 1817) (DIPTERA: MUSCIDAE) em laboratório. Arquivos do Instituto Biológico, v.73, n.2, p.203-209, 2006.

ZOU, Y.; VAN DER WERF, W.; LIU, Y.; AXMACHER, J. C. Predictability of species diversity by family diversity across global terrestrial animal taxa. Global Ecology Biogeograph, v.29, p.629-644, 2020.

A CBPC - Companhia Brasileira de Produção Científica (CNPJ: 11.221.422/0001-03) detém os direitos materiais desta publicação. Os direitos referem-se à publicação do trabalho em qualquer parte do mundo, incluindo os direitos às renovações, expansões e disseminações da contribuição, bem como outros direitos subsidiários. Todos os trabalhos publicados eletronicamente poderão posteriormente ser publicados em coletâneas impressas sob coordenação da Sustenere Publishing, da Companhia Brasileira de Produção Científica e seus parceiros autorizados. Os (as) autores (as) preservam os direitos autorais, mas não têm permissão para a publicação da contribuição em outro meio, impresso ou digital, em português ou em tradução. 